\title{
Virus-Infected Human Mast Cells Enhance Natural Killer Cell Functions
}

\author{
Liliana Portales-Cervantes $^{a}$ Ian D. Haidl ${ }^{a}$ Patrick W. Lee ${ }^{a, b}$ Jean S. Marshalla, b \\ Departments of ${ }^{a}$ Microbiology and Immunology and ${ }^{b}$ Pathology, Dalhousie University, Halifax, N.S., Canada
}

\section{Key Words}

Mast cells · Natural killer cells · Innate immunity · Viral

infection · Interferons · Cytokines · Allergy sponse, not shared by structural cells, and a subsequent novel mast cell-NK cell immune axis in human antiviral host defense.

(c) 2016 S. Karger AG, Basel

\begin{abstract}
Mucosal surfaces are protected from infection by both structural and sentinel cells, such as mast cells. The mast cell's role in antiviral responses is poorly understood; however, they selectively recruit natural killer (NK) cells following infection. Here, the ability of virus-infected mast cells to enhance NK cell functions was examined. Cord blood-derived human mast cells infected with reovirus (Reo-CBMC) and subsequent mast cell products were used for the stimulation of human NK cells. NK cells upregulated the CD69 molecule and cytotoxicity-related genes, and demonstrated increased cytotoxic activity in response to Reo-CBMC soluble products. NK cell interferon (IFN)- $\gamma$ production was also promoted in the presence of interleukin (IL)-18. In vivo, SCID mice injected with Reo-CBMC in a subcutaneous Matrigel model, could recruit and activate murine NK cells, a property not shared by normal human fibroblasts. Soluble products of Reo-CBMC included IL-10, TNF, type I and type III IFNs. Blockade of the type I IFN receptor abrogated NK cell activation. Furthermore, reovirus-infected mast cells expressed multiple IFN- $a$ subtypes not observed in reovirus-infected fibroblasts or epithelial cells. Our data define an important mast cell IFN re-
\end{abstract}

\section{Introduction}

Mucosal surfaces are the main route of entry for viruses into the body and the site for the development of infections [1]. The recruitment of cytotoxic effector cells and the generation of antiviral cytokines, such as interferons (IFNs), by sentinel cells are known to be important in limiting or eliminating viral infection. However, the mechanism(s) by which these responses are locally coordinated is unclear.

Natural killer (NK) cells are a key component of the innate immune system, essential for optimal host defense, and found in multiple tissues where they have a key role in early immunity to cancer and viruses by killing a variety of tumor and virus-infected cells without prior sensitization. NK cells produce cytokines such as IFN- $\gamma$, which

A portion of this work was previously presented as anabstract at The American Association of Immunologist Annual Meeting in 2015. The abstracts from this meeting were published in the Journal of Immunology (J Immunol 2015;194:suppl).

\section{KARGER}

() 2016 S. Karger AG, Basel

E-Mail karger@karger.com

www.karger.com/jin
Dr. Jean S. Marshall

Department of Microbiology and Immunology, Dalhousie University

Room 15-E4, 5850 College Street

Halifax, NS B3H 4R2 (Canada)

E-Mail jean.marshall@ dal.ca 
promote the activation of other immune effector cells [2]. Optimal function of NK cells is under the control of microenvironmental signals and is tightly regulated by the interplay between inhibitory and activating receptors [3]. Local cytokines such as interleukin (IL)-10, IL-12, IL-15, IL-18 and IFNs are known to regulate NK cell responses [4]. However, the mechanisms by which NK cells are locally activated early in viral infections are not well characterized.

Mast cells are highly specialized immune cells and prominent residents of mucosal and epithelial tissues. They are well known for their detrimental role in allergy. However, they are also important sentinel cells in bacterial and parasitic infections [5]. Mast cells play a crucial role in early immunity, primarily through enhancing effector cell and dendritic cell (DC) mobilization [6]. The mast cell's role in antiviral immunity is also becoming recognized. Recent evidence demonstrates that human mast cells respond to multiple viruses including influenza A virus, reovirus and herpes simplex virus through the selective production of proinflammatory cytokines [7-9]. Our group has previously shown that human mast cells express a range of cytokines and chemokines, some of which selectively recruit NK cells in models of viral infection [9]. Although these data suggest an important role for mast cells during viral infections, the consequences of human mast cell activation by viruses for other aspects of the innate immune response are unknown. Early control of many virus infections necessitates both the recruitment of NK cells and their subsequent activation. The aim of this study was to analyze the mediators produced by human mast cells, compared with other resident tissue cells, in response to reovirus infection and to determine their impact on NK cell function.

Reoviruses are double-stranded-RNA, nonenveloped viruses associated with mild respiratory or gastrointestinal symptoms [10]. Mammalian reovirus type 3 Dearing was used as a model since it induces a successful host response to infection and infects multiple cell types such as immune cells, epithelial cells, cardiac myocytes and fibroblasts $[9,11-13]$. In addition, this mucosal pathogen is associated with the development of a highly effective antiviral immune response at mast cell-rich tissue sites [10] and has been employed in oncolytic therapies for solid tumors [14].

Our results show that soluble mediators produced by virus-infected human mast cells induced NK cell activation and enhanced NK cell cytotoxicity, primarily by mechanisms dependent on mast cell type I IFN expression and not on mast cell-derived type III IFNs or IL-10.
In vivo, reovirus-infected human mast cells, but not reovirus-infected human fibroblasts, recruited and activated murine NK cells. While most cells are capable of producing some type I IFNs during viral infection, the combined production of high levels of a wide variety of type I IFNs and NK chemoattractants by mast cells is unusual. We have demonstrated that reovirus-infected mast cells produce a variety of IFN- $\alpha$ subtypes and IFN- $\beta$ in much greater amounts than those contributed by normal human lung fibroblasts (NHLF) or epithelial cells. Taken together, our results define an important mast cell IFN response, not shared by structural cells, and the subsequent novel mast cell-NK cell immune axis in the human antiviral host defense.

\section{Methods}

Mice

Male nonobese diabetic mice homozygous for the severe combined immune deficiency spontaneous mutation Prkdc ${ }^{\text {scid }}$ (NOD SCID mice) were purchased from Jackson Laboratories (Bar Harbor, Me., USA). Mice, 14-21 weeks of age, were used for experiments and housed in a pathogen-free facility following the guidelines established by the Canadian Council on Animal Care.

\section{Cell Cultures}

Cord blood-derived mast cells (CBMC) were generated by long-term culture of cord blood-derived cells according to an adaptation of the method described by Enoksson et al. [15]. Briefly, mononuclear cells obtained from umbilical cord blood were cultured at $1.0 \times 10^{6}$ cells $/ \mathrm{ml}$ and passaged once per week for 4 weeks in StemSpan SFEM medium (Stem Cell Technologies, Vancouver, B.C., Canada) containing $10 \mathrm{ng} / \mathrm{ml} \mathrm{hIL-3}$ (present only for the first week of culture, eBiosciences, San Diego, Calif., USA), $10 \mathrm{ng} / \mathrm{ml}$ hIL-6 and 100 ng/ml hSCF (Peprotech, Rocky Hill, N.J., USA) in $5 \% \mathrm{CO}_{2}$ at $37^{\circ} \mathrm{C}$ in humidified atmosphere. At 5 weeks of culture, the medium was replaced by RPMI 1640 (Sigma, St Louis, Mo., USA) supplemented with $10 \%$ fetal bovine serum (FBS; Sigma), 2 mM L-glutamine (Hyclone Labs, Thermo Scientific, Rockford, Ill., USA), $1 \times$ penicillin/streptomycin (P/S; HyClone), $5 \times 10^{-5} \mathrm{M}$ 2-mercaptoethanol (Sigma), $15 \mathrm{mM}$ HEPES (HyClone), $0.1 \mathrm{mM}$ nonessential amino acids (HyClone), $100 \mathrm{ng} / \mathrm{ml} \mathrm{hSCF}$ and $10 \mathrm{ng} /$ $\mathrm{ml}$ hIL-6. Mast cell purity was evaluated by surface expression of c-Kit/CD117 at week 6 . The purity of mast cells used in the experiments was $\geq 95 \%$. Typically, CBMC cultures were devoid of DC and $>99 \%$ positive for tryptase. NHLF (CCL-204) and Calu-3 cells were purchased from ATCC (Manassas, Va., USA) and cultured in RPMI supplemented with $10 \%$ FBS or Dulbecco's modified Eagle medium/Ham's F-12 nutrient mixture (Thermo Fisher Scientific) supplemented with $10 \%$ FBS, respectively. Normal human bronchial epithelial cells (NBEC, Lonza, Workingham, UK) were cultured in growth factor-supplemented bronchial epithelial cell medium (Lonza) following the manufacturer's instructions. Conventional DC were differentiated in vitro from peripheral monocytes. Briefly, peripheral blood mononuclear cells (PBMC) 
were isolated from healthy donors using lymphoprep (Stem Cell Technologies). $\mathrm{PBMC}$ were cultured at $37^{\circ} \mathrm{C}$ for $2 \mathrm{~h}$ and nonadherent cells were washed out. To generate monocyte-derived DC (MDDC), adherent cells were cultured in RPMI supplemented with 10\% FBS, 50 ng/ml GM-CSF (BioLegend, San Diego, Calif., USA), $50 \mathrm{ng} / \mathrm{ml} \mathrm{IL-4} \mathrm{(BioLegend),} 40 \mu \mathrm{g} / \mathrm{ml}$ gentamycin (Sigma) and $100 \mathrm{ng} / \mathrm{ml}$ polymyxin B sulfate (Sigma). Fresh supplemented medium (without gentamycin) was added every 2 days. Nonadherent cells were harvested at day 6 of culture.

\section{Reovirus Infection}

CBMC, Calu-3 cells, NHLF and MDDC were incubated with reovirus at $20 \mathrm{MOI}$ for $1 \mathrm{~h}$ at $37^{\circ} \mathrm{C}$ and then washed and placed in RPMI medium (Hyclone) supplemented with 1\% FBS (Sigma) plus $1 \%$ nonessential amino acids (Hyclone) for NHLF or $10 \mathrm{ng} /$ $\mathrm{ml} \mathrm{hSCF}$ for CBMC (Peprotech) with $100 \mu \mathrm{g} / \mathrm{ml}$ soybean trypsin inhibitor (Sigma). UV light-inactivated reovirus (UV-Reo) was used as negative control.

\section{Reovirus-Infected CBMC Supernatants}

Reovirus-infected CBMC (Reo-CBMC) supernatants (sn) were treated with UV light, using the UV Crosslinker chamber (UVP, Upland, Calif., USA) in order to inactivate viral particles. UV-Reo CBMC and uninfected CBMC (Mock-CBMC) sn underwent the same UV light treatment.

\section{mRNA Analysis}

Gene expression was analyzed using primers from Bio-Rad (IFNA10, IFNA17 and IFNA21) or Qiagen (type I IFNs, PRF1, GZMB and TIA-1) and GoTaq qPCR master mix (Promega, Madison, Wis., USA) in a Stratagene Mx Pro 3000P qPCR system (Qiagen).

\section{Cytokine Production by Reo-CBMC}

Cytokines were determined by ELISA according to the manufacturer's instructions to detect IL-21, IL-18, IFN- $\lambda 1$ (eBiosciences) and IL-33 (R\&D Systems, Minneapolis, Minn., USA). IL-1 $\beta$, IL-2, IL-4, IL-10, IL-12, IL-13, IL-15, IFN- $\alpha 2$, IFN- $\beta$, TNF and IFN- $\gamma$ were measured using the Bio-Plex Pro human cytokine assay (Bio-Rad, Mississauga, Ont., Canada).

\section{Human NK Cell Isolation}

NK cells were purified from PBMC with an EasySep human NK cell enrichment kit (Stem Cell Technologies). Cells used for mRNA analysis were $92.1 \pm 3.2 \% \mathrm{CD}^{-} \mathrm{CD}^{+} 6^{+}$.

\section{NK Cell Stimulation}

NK cells were incubated with RPMI supplemented with $10 \%$ FBS (10\% RPMI), Mock-CBMC sn, Reo-CBMC sn, $10 \mathrm{ng} / \mathrm{ml}$ human IFN- $\alpha 2$ (US Biological, Salem, Mass., USA), $100 \mathrm{ng} / \mathrm{ml}$ hIFN- $\lambda 1$ (Peprotech) or $10 \mathrm{ng} / \mathrm{ml}$ IL-10 (Peprotech) for $24 \mathrm{~h}$. For IFN- $\gamma$ production, $100 \mathrm{ng} / \mathrm{ml}$ of IL-18 (R\&D Systems) was added to the NK cells cultured in the presence of CBMC sn.

\section{In vivo Matrigel NK Cell Activation}

Reo-CBMC, UV-Reo CBMC, Reo-NHLF, Mock-CBMC and Mock-NHLF were resuspended at $3.5 \times 10^{6}$ cells $/ \mathrm{ml}$ in growth factor-reduced Matrigel (BD Biosciences, San José, Calif., USA). NOD SCID mice were injected subcutaneously at 4 sites with 200$\mu$ suspensions ( 2 sites Reo cells and 2 sites with either uninfected or UV-Reo cells). Mice were euthanized $24 \mathrm{~h}$ after injection. The Matrigel sites were harvested and treated with digestion buffer (2.24 U/ml dispase, $100 \mu \mathrm{g} / \mathrm{ml} \mathrm{DNAse)} \mathrm{prior} \mathrm{to} \mathrm{cell} \mathrm{analysis} \mathrm{by} \mathrm{flow}$ cytometry.

\section{Flow Cytometric Analysis}

Mouse cells recruited to Matrigel sites were stained with biotinylated anti-CD49b and SA-PE, anti-CD69-FITC and anti-CD45APC antibodies. Human NK cells were stained with biotinylated anti-CD69 and SA-FITC. Intracellular IFN- $\gamma$ was analyzed with an anti-IFN- $\gamma$-APC. Antibodies were all obtained from eBiosciences. Reovirus infection was analyzed by intracellular staining using an anti-reovirus polyclonal rabbit antibody followed by anti-rabbit IgG-Alexa Fluor 488 (Molecular Probes, Invitrogen). For all conditions, Fc receptors were blocked with $100 \mu \mathrm{g} / \mathrm{ml}$ hIgG. Samples were analyzed using a BD FACSCalibur flow cytometer (BD Biosciences).

\section{Cytotoxicity Assay}

Cytotoxicity was evaluated by a CytoTox 96 nonradioactive cytotoxicity assay (Promega). Briefly, human NK cells were resuspended in Reo-CBMC sn or Mock-CBMC sn. NK cells were cultured in U-bottom 96-well microwell plates (Thermo Scientific) at ratios of 2:1 and 4:1 (effector:target, E:T) in the presence of 5,000 cells/well of the target cell line K562 (ATCC, Manassas, Va., USA) and incubated for $4 \mathrm{~h}$ at $37^{\circ} \mathrm{C}$. All conditions were carried out in triplicate. Target cell maximum release (TM) was determined by lysing K562 cells with $10 \mu \mathrm{l}$ of lysis solution. Target cell spontaneous release (TS) was determined by the incubation of K562 cells in either Mock-CBMC or Reo-CBMC sn in the absence of effector NK cells. Effector cell spontaneous release (ES) was measured with the corresponding NK cell concentration in the absence of the target cells. NK cytotoxicity rate (\%) was calculated as follows $=[($ Experimental - ES $-\mathrm{TS}) /(\mathrm{TM}-$ TS) $] \times 100$.

\section{Type I IFN Receptor Blockade}

Human NK cells were pretreated with $5 \mu \mathrm{g} / \mathrm{ml}$ of either mouse anti-human IFN receptor (IFNAR) chain 2 (IFNAR2, Calbiochem, San Diego, Calif., USA) or $5 \mu \mathrm{g} / \mathrm{ml}$ of mouse IgG2a (BioLegend) for $1.5 \mathrm{~h}$ at $37^{\circ} \mathrm{C}$, followed by the addition of Reo-CBMC sn.

\section{Statistics}

For comparison of matched groups, depending upon data distribution (normality test), the paired t test or the Wilcoxon matched test were performed. Repeated-measures ANOVA and the Tukey post hoc test were used for comparisons of multiple groups. Differences were considered significant at $\mathrm{p}<0.05$. Statistical analyses were performed using InStat software v3.10 (GraphPad Software Inc., San Diego, Calif., USA).

\section{Study Approval}

Umbilical cord blood samples were obtained following the approval of the research ethics board of the Izaak Walton Killam Health Centre, Halifax, N.S., Canada. Adult blood donors provided written informed consent. Experiments involving animals were performed according to protocols approved by the animal research ethics board of Dalhousie University (Halifax, N.S., Canada). 

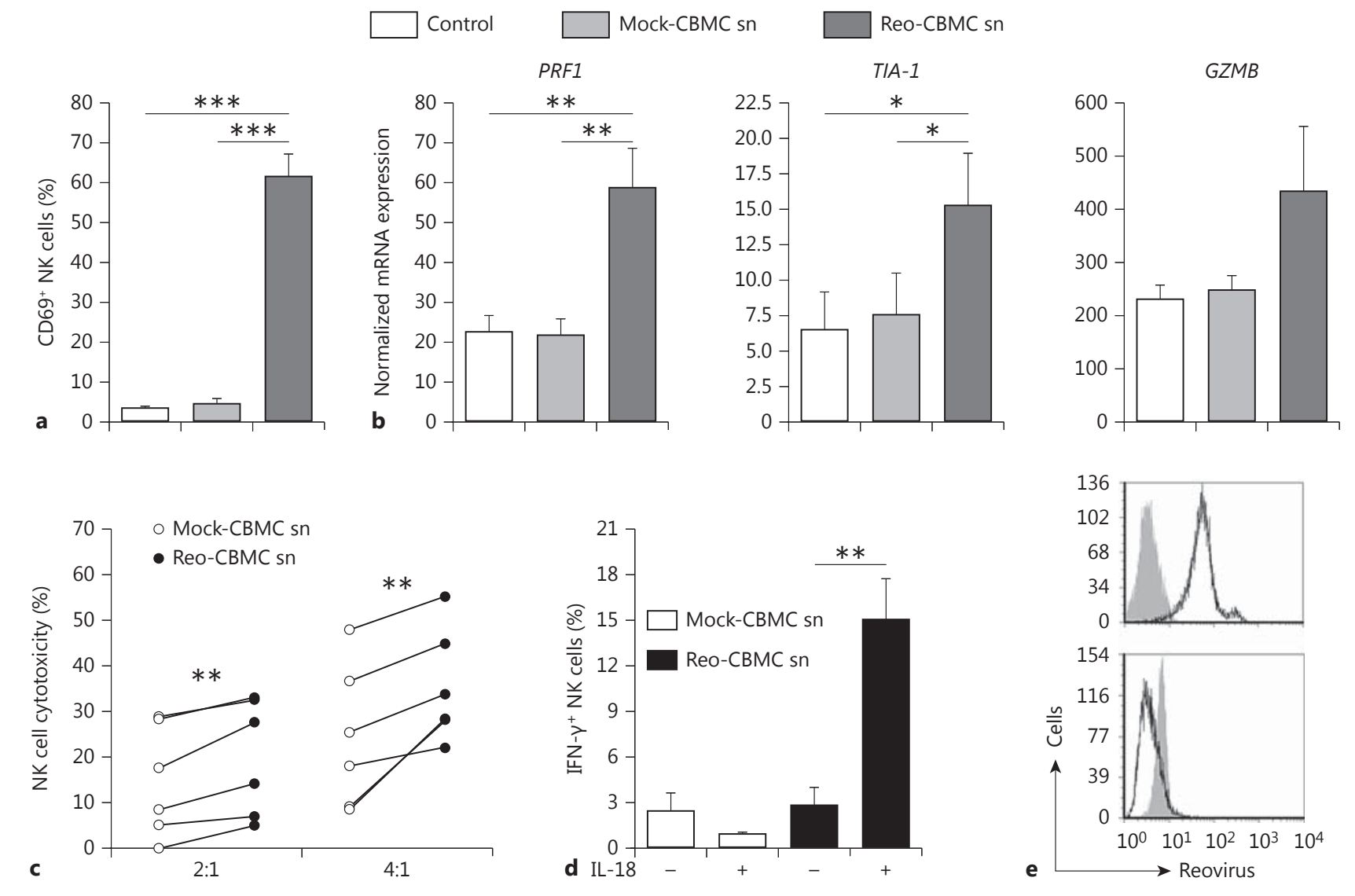

Fig. 1. Soluble mediator(s) produced by reovirus-infected mast cells activate NK cells. Purified peripheral blood human NK cells were cultured in Mock-CBMC sn, Reo-CBMC sn or culture medium (Control) for $24 \mathrm{~h}$. a A purified lymphocyte population ( $\geq 90 \% \mathrm{CD}^{-} \mathrm{CD}^{2} 6^{+}$cells) was analyzed for CD69 expression by FACS $(\mathrm{n}=7)$. b PRF1 $(\mathrm{n}=6)$, TIA-1 $(\mathrm{n}=5)$ and GZMB $(\mathrm{n}=5)$ gene expression was analyzed by qPCR and shown as normalized to GAPDH. c NK cells were resuspended in either Mock-CBMC sn or Reo-CBMC sn and cytotoxic activity against the K562 cell line was analyzed by LDH release assay at ratios of 2:1 and 4:1 (E:T) after $4 \mathrm{~h}$ of coculture $(n=6)$. All conditions were carried out in triplicate. $\mathbf{d}$ IFN- $\gamma$ production was determined following stimula-

\section{Results}

\section{Mediators Produced by Mast Cells in Response to Reovirus Infection Activate NK Cells}

Activated NK cells have enhanced cytotoxic function which results in the recognition and killing of a range of transformed and infected cells that are not lysed by resting NK cells [16]. Therefore, the ability of soluble mediators produced by virus-infected mast cells to enhance NK tion with either Mock-CBMC sn or Reo-CBMC sn in the presence $(+)$ or absence $(-)$ of $100 \mathrm{ng} / \mathrm{ml}$ IL-18 $(\mathrm{n}=7)$. Samples were analyzed by FACS. Data were compared using repeated-measures ANOVA with the Tukey post hoc test $(\mathbf{a}, \mathbf{b})$ or paired t test $(\mathbf{c}, \mathbf{d})$. ${ }^{*} \mathrm{p}<0.05,{ }^{* *} \mathrm{p}<0.01,{ }^{* * *} \mathrm{p}<0.001$. Results are presented as mean \pm SEM from at least 3 independent experiments performed on at least 5 different donors. e Reovirus infection was analyzed by FACS in CBMC (upper panel, $\mathrm{n}=6$ ) and NK cells (lower panel, $\mathrm{n}=2$ ) after culture with $20 \mathrm{MOI}$ reovirus or Reo-CBMC sn, respectively. Isotype control (filled histograms) and anti-reovirus (empty histograms and black line) are shown.

cell functions was analyzed. NK cells upregulated the activation marker CD69 in response to sn derived from Reo-CBMC (Reo-CBMC sn) (fig. 1) but not control sn. CD69 expression is associated with the enhanced cytotoxic activity of NK cells [17]. The expression of genes related to the granule exocytosis NK cytotoxicity pathway, perforin 1 (PRF1) and granzyme B (GZMB), and of the TIA-1 gene, which encodes an apoptosis-inducing RNA-binding protein in cytotoxic granules [18], was ex- 
amined. Both PRF1 and TIA-1 mRNA levels were consistently enhanced upon stimulation with Reo-CBMC sn compared with controls. NK cells from $3 / 5$ donors also demonstrated enhanced expression of GZMB in response to Reo-CBMC sn (fig. 1b). In order to analyze if the cytotoxic activity of NK cells was in fact enhanced by soluble mediator(s) derived from reovirus-infected human mast cells, NK cells from 6 donors were cocultured with K562 tumor cells in the presence of Reo-CBMC sn or MockCBMC sn. The K562 cell line, an NK cell-sensitive target in widespread use for the analysis of NK cytotoxic activity, was chosen as an appropriate NK target rather than reovirus-infected cells since reovirus type 3 Dearing is highly lytic in many cell types and infects multiple cell types including, potentially, NK cells $[9,11-13]$. Enhanced cytotoxic activity against K562 cells was consistently observed when NK cells were treated with ReoCBMC sn compared to sn derived from uninfected mast cell cultures (Mock-CBMC sn) (fig. 1c), indicating that virus-infected mast cells produce soluble mediator(s) that enhance the cytotoxic activity of NK cells. K562 cultured alone in CBMC sn did not undergo cell lysis (data not shown).

IFN- $\gamma$ production is also characteristic of activated NK cells. The activation of NK cells can be regulated by cytokines such as IL-18, which can be produced by macrophages during viral infections [19]. IL-18 has been shown to act in synergy with other cytokines to induce NK cell IFN- $\gamma$ production $[4,20]$. An increased production of IFN- $\gamma$ was observed when NK cells were stimulated with Reo-CBMC sn in the presence of exogenous IL-18 (fig. 1d).

To further confirm that activation of NK cells by mast cell sn was not the result of residual active reovirus, despite UV light inactivation treatment, the intracellular presence of the virus was analyzed by FACS in NK cells after $24 \mathrm{~h}$ of culture with the previously UV-treated, ReoCBMC sn. No infection of NK cells by reovirus was observed under these conditions (fig. 1e).

Virus-Infected Human Mast Cells Induce Recruitment and Activation of NK Cells in vivo

Both NK cell attracting chemokines and type I IFNs are known to act across the human-to-mouse species barrier $[21,22]$. To investigate the ability of mast cells to induce NK cell activation at sites of viral infection, NOD SCID mice were injected with CBMC in Matrigel suspensions (CBMC Mat) following treatment of the mast cells with active reovirus or UV-Reo. NK cells from NOD SCID mice migrate normally, but have reduced NK cell cytotoxic function [23] and so these mice are excellent recipients of human hematopoietic cells. CBMC sn were not included in this analysis so as to ensure the maintenance of a chemoattractant gradient and avoid diluting the Matrigel. At mucosal surfaces, viruses infect both structural and immune sentinel cells. Therefore, we compared mast cell IFN responses with those of NHLF and human epithelial cells. Matrigel sites containing uninfected epithelial cells resulted in an extremely high background and the recruitment and activation of a range of murine inflammatory cells (data not shown). Consequently, this cell type was excluded from our in vivo analysis. An elevated number of $\mathrm{CD}_{4} 9 \mathrm{~b}^{+} \mathrm{NK}$ cells were recruited to the Matrigel sites containing Reo-CBMC (ReoCBMC Mat) in comparison to Matrigel sites with CBMC treated with UV-Reo (UV-Reo CBMC Mat) (fig. 2a). We also analyzed if immune cells other than NK cells were recruited by virus-infected mast cells. An enhanced number of neutrophils were recruited to Reo-CBMC Mat sites (online suppl. fig. S1; for all online suppl. material, see www.karger.com/doi/10.159/000450576). However, this difference was not statistically significant in comparison to uninfected mast cells ( $p>0.05$, paired t test). Monocyte and macrophage numbers were similar at the MockCBMC Mat and Reo-CBMC Mat sites (online suppl. fig. S1). The Matrigel-only sites demonstrated little cell recruitment $\left(\mathrm{n}=2\right.$; average $=4.1 \times 10^{4}$ cells $)$ compared to the Mock-CBMC Mat $\left(\mathrm{n}=4 ; 3.3 \times 10^{5}\right.$ recruited cells) and Reo-CBMC Mat ( $\mathrm{n}=4 ; 6.08 \times 10^{5}$ recruited cells) (data not shown).

Mock-NHLF and Reo-NHLF induced a similar recruitment of NK cells (fig. 2a), which was not significant different to Reo-CBMC Mat ( $p>0.05$, unpaired $t$ test). The high baseline NK cell recruitment observed in response to Mock-NHLF could be attributed to the constitutive expression of chemokines such as IL-8, CXCL12 and CCL-2 [24]. The activation status of recruited CD49b ${ }^{+}$ NK cells was also determined. Because of either not detectable or extremely low NK cell recruitment for many sites in response to UV-Reo CBMC, the results from Matrigel sites containing either UV-Reo CBMC $(n=1)$ or Mock-CBMC $(n=4)$, where $\geq 0.5 \%$ of NK cells were recruited, were pooled in order to analyze the level of activation of NK cells recruited to sites of uninfected mast cells. NK cells recruited to Reo-CBMC Mat showed increased expression of CD69 when compared with NK cells recruited to Control-CBMC Mat (fig. 2b). Neither of the fibroblast-containing conditions induced activation of NK cells (fig. 2b). Our results demonstrate that infected human mast cells induced both the recruitment and 

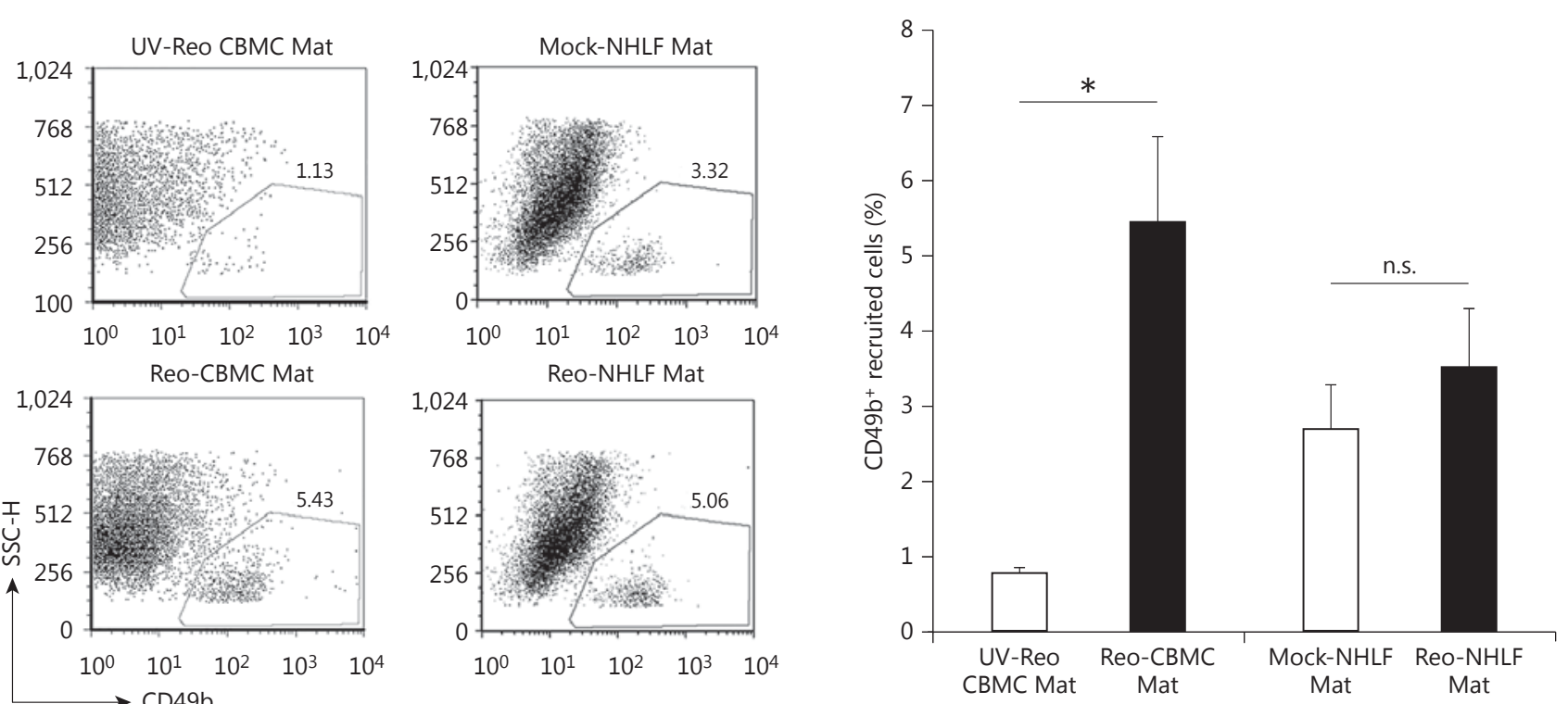

a
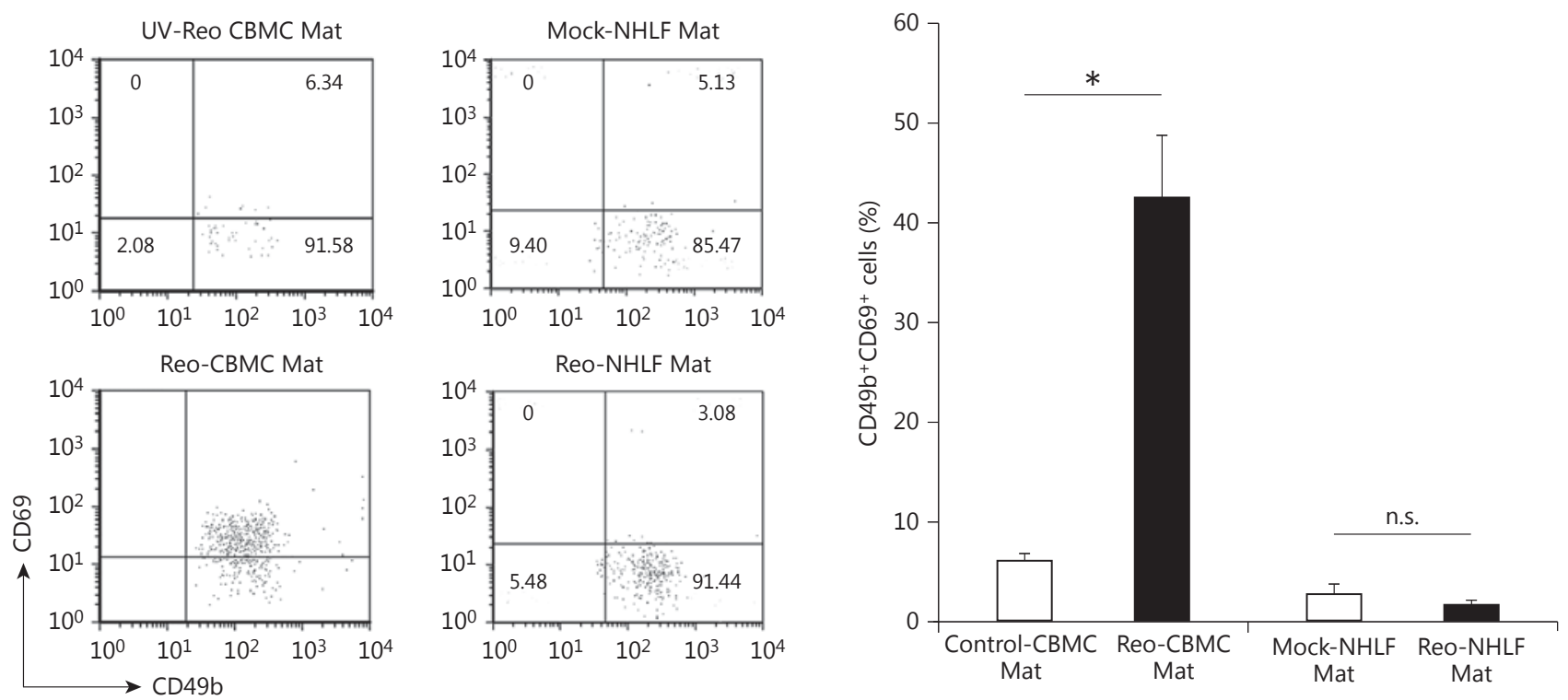

b

Fig. 2. NK cell recruitment and activation by reovirus-infected mast cells in vivo. Individual NOD SCID mice were each subcutaneously injected with Matrigel (Mat) containing cells under 2 different conditions, Reo-CBMC and either UV-Reo CBMC or Mock-CBMC. Similarly, NOD SCID mice received injections containing Reo-NHLF Mat and Mock-NHLF Mat. Matrigel plugs were harvested $24 \mathrm{~h}$ after injection. a Recruitment of NK cells was analyzed by FACS, first gating the leukocyte population by CD45 expression. CD $49 b^{+}$cells were analyzed within this gate. $\mathbf{b}$ NK cell activation was determined by CD69 expression within the gate of
$\mathrm{CD}_{4} \mathrm{~b}^{+}$cells. Control-CBMC Mat includes pooled results from both UV-Reo CBMC Mat $(n=1)$ and Mock-CBMC Mat $(n=4)$, which represent those control sites where sufficient NK cell recruitment occurred for analysis of cell activation. Results from the 5 animals where both control and Reo-CBMC Mat data were available were compared using the paired t test. ${ }^{*} \mathrm{p}<0.05$; all the available data from 9 (CBMC) or 6 (NHLF) NOD SCID are represented graphically as mean \pm SEM from at least 5 independent experiments with at least 2 mice. $n . s .=$ Not significant. 


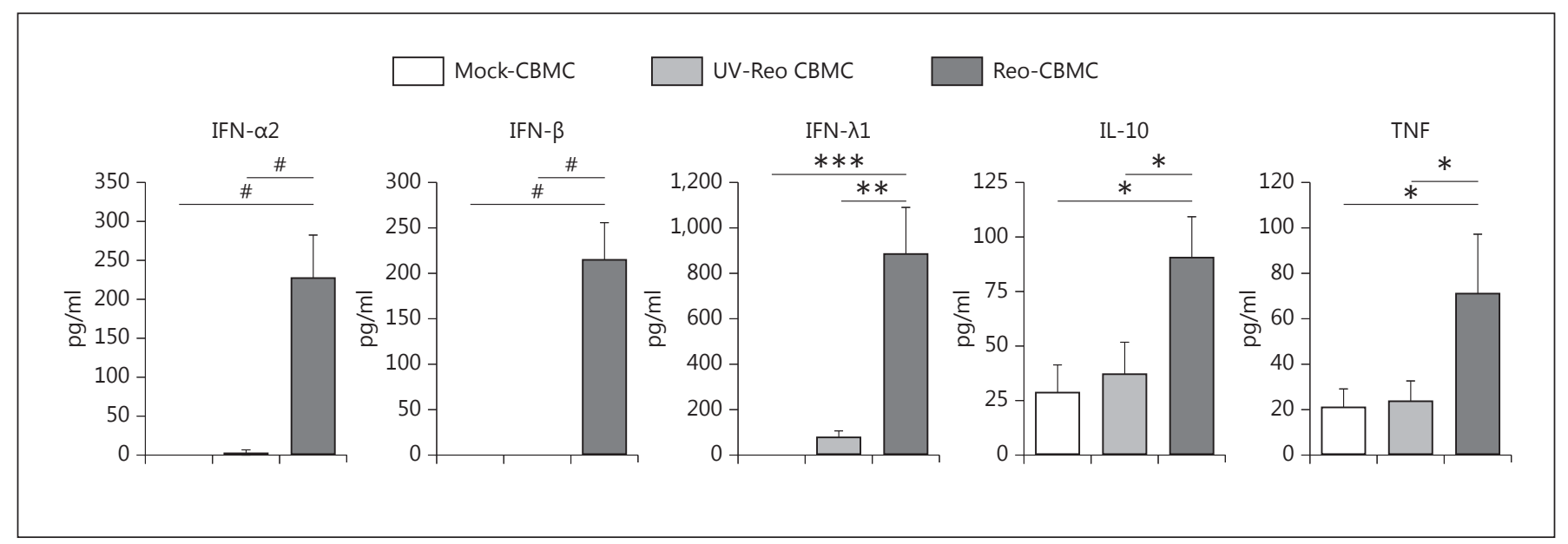

Fig. 3. Cytokines produced by reovirus-infected mast cells. CBMC were infected with 20 MOI reovirus, cultured with 20 MOI UV-Reo or left uninfected for $24 \mathrm{~h}$. Mast cell culture sn were analyzed by ELISA or multiplex to determine the production of IFN- $\alpha 2(n=6)$, IFN- $\beta(n=5)$, IFN- $\lambda 1(n=8)$, IL-10 $(n=6)$, and TNF $(n=6)$. Data were compared using repeated measures with the Tukey $\left(^{*}\right)$ or Dunn $(\#)$ post hoc test. ${ }^{*}, \# \mathrm{p}<0.05,{ }^{* *} \mathrm{p}<0.01$, *** $\mathrm{p}<0.001$. Results are presented as the mean \pm SEM.

activation of NK cells, while infected fibroblasts recruited NK cells but did not induce their activation.

\section{NK Cell-Activating Cytokines Produced by}

\section{Virus-Infected Human Mast Cells}

Reo-CBMC sn were analyzed for potential NK cell-activating cytokines $[4,20]$. IL-2, IL-15, IL-18, IL-21, IL-1 $\beta$, IL-13 and IL-33 levels were low and similar in MockCBMC, UV-Reo CBMC and Reo-CBMC sn (table 1). However, greater amounts of IFN- $\alpha 2$, IFN- $\beta$ (type I IFN), IFN- $\lambda 1$ (type III IFN), TNF and IL-10 were found in the sn from reovirus-infected human mast cells than from either control cells or UV-Reo-treated cells (fig. 3). TNF can synergize with IL- 12 to induce IFN- $\gamma$ production by NK cells $[4,20]$. However, IL-12 was only produced at low levels by reovirus-infected mast cells $(20.4 \pm 11 \mathrm{pg} / \mathrm{ml})$. Consistent with these findings, IFN- $\gamma$ production was not induced from the NK cells by stimulation with mediators from reovirus-infected mast cells alone (fig. 1d). Despite its well-described anti-inflammatory properties, several reports show that IL-10 can enhance the function of NK cells $[18,25]$. Type I IFNs are produced in response to viral infections and are involved in the regulation of NK cell cytotoxic activity $[20,26]$. Recently described, type III IFNs share a similar expression pattern and biological activities to type I IFNs [27]. Overall, our results suggested that mast cell-derived IL-10, IFN- $\lambda 1$ and type I IFNs were candidate mast cell mediators involved in NK cell activation (fig. 1).
Table 1. Cytokines produced by Reo-CBMC

\begin{tabular}{lcll}
\hline Cytokine & $\begin{array}{l}\text { Mock-CBMC } \\
\text { sn, pg/ml }\end{array}$ & $\begin{array}{l}\text { UV-Reo CBMC } \\
\text { sn, pg/ml }\end{array}$ & $\begin{array}{l}\text { Reo-CBMC } \\
\text { sn, pg/ml }\end{array}$ \\
\hline IL-12 & $14.9 \pm 8.8$ & n.d. & $20.4 \pm 11$ \\
IL-15 & $7.6 \pm 0.2$ & n.d. & $11.9 \pm 9.3$ \\
IL-18 & $<15.6$ & $<15.6$ & $<15.6$ \\
IL-21 & $<20$ & $<20$ & $<20$ \\
IL-1 $\beta$ & $4.2 \pm 4.9$ & n.d. & $7.5 \pm 3.6$ \\
IL-13 & $3.3 \pm 0.8$ & $4.73 \pm 4.45$ & $8 \pm 3.9$ \\
IL-33 & $<15.6$ & $<15.6$ & $<15.6$ \\
IFN- $\gamma$ & $65 \pm 6$ & $58.87 \pm 6.05$ & $66.9 \pm 8.7$ \\
\hline
\end{tabular}

Data are presented as mean \pm SEM $(n=6)$. n.d. $=$ Not determined.

\section{NK Cell Responses to Cytokines Produced by}

Reo-CBMC

In order to analyze the role of IFNs and IL-10, purified human NK cells were stimulated in parallel with ReoCBMC sn, type I IFN (IFN- $\alpha 2)$, type III IFN (IFN- $\lambda 1$ ) or IL-10. Medium alone (control) and Mock-CBMC sn were used as negative controls. Only IFN- $\alpha 2$ (IFN- $\alpha$ ) and ReoCBMC sn significantly induced the expression of CD69 (fig. 4a). In addition, IFN- $\alpha$ induced the expression of $P R F 1$, similar to Reo-CBMC sn, and to a higher level than that observed following treatment with products of unin- 
fected mast cells (fig. $4 \mathrm{~b}$ ). Neither IFN- $\lambda 1$ nor IL-10 stimulation induced significant changes in CD69 and PRF1 expression compared to control-treated cells (fig. $4 \mathrm{a}, \mathrm{b}$ ).

Since the induction of IFN- $\gamma$ in NK cells by Reo-CBMC sn was dependent on IL-18 (fig. 1d), the ability of IFN- $\alpha$, together with IL-18, to induce IFN- $\gamma$ in NK cells was analyzed. The percentage of IFN- $\gamma^{+}$NK cells was similar in the presence of either recombinant IFN- $\alpha$ or the products of reovirus-infected mast cells, in combination with IL-18 (fig. 4c). The addition of IFN- $\alpha$ alone to Reo-CBMC sn did not enhance the percentage of IFN $-\gamma^{+}$NK cells $(\mathrm{n}=$ 4; data not shown). Overall, IFN- $\alpha$, but not IL-10 or IFN- $\lambda 1$, induced the activation of NK cells, similar to that observed in response to Reo-CBMC sn.

\section{Mast Cell-Derived Type I IFNs Regulate NK Cell Responses}

To confirm the role of mast cell-derived type I IFNs in NK cell activation, purified NK cells were treated with a blocking antibody against the IFNAR prior to stimulation with Reo-CBMC sn. Blockade of the IFNAR on NK cells completely inhibited the expression of CD69 in response to stimulation with Reo-CBMC sn. An isotype-matched control antibody did not modify CD69 expression (fig. 5a). The mast cell-mediated increase in both $P R F 1$ and TIA-1 gene expression was also significantly inhibited by blockade of IFNAR (fig. 5b). GZMB gene expression changes were inconsistent between donors. IFN- $\gamma$ production in response to Reo-CBMC sn plus IL-18 was also abrogated when IFNAR on NK cells was blocked (fig. 5 c). In $3 / 8$ donors, a decrease in IFN- $\gamma$ production by NK cells cultured with an isotype control was observed (fig. 5c). However, the overall production of IFN- $\gamma$ by NK cells in the presence of an isotype control was significantly higher than by NK cells cultured with Reo-CBMC sn alone $(\mathrm{p}<0.05)$. In addition, no significant difference was observed in IFN- $\gamma$ production when compared to NK

Fig. 4. Response of NK cells to cytokines produced by reovirusinfected mast cells. NK cells were stimulated in parallel with ReoCBMC sn, $10 \mathrm{ng} / \mathrm{ml}$ IFN- $\alpha 2 \mathrm{a}, 100 \mathrm{ng} / \mathrm{ml}$ IFN- $\lambda 1$ or $30 \mathrm{ng} / \mathrm{ml}$ IL-10 for $24 \mathrm{~h}$. Mock-CBMC sn and 10\% RPMI (control) were used as negative controls of stimulation. a CD69 upregulation $(n=5)$ was analyzed by FACS. $\mathbf{b} P R F 1$ gene expression $(\mathrm{n}=6)$ was analyzed by qPCR. Results are shown as normalized to GAPDH. c For IFN- $\gamma$ production $(n=5)$, IL-18 was added when indicated. Intracellular IFN- $\gamma$ was analyzed by FACS. Data were compared using repeated-measures ANOVA with the Tukey post hoc test. ${ }^{*} \mathrm{p}<0.05$, ${ }^{* *} \mathrm{p}<0.01,{ }^{* * *} \mathrm{p}<0.001$. Results are presented as the mean \pm SEM from at least 3 independent experiments performed on at least 5 different donors. n.s. $=$ Not significant.

Virus-Infected Mast Cells Activate NK Cells

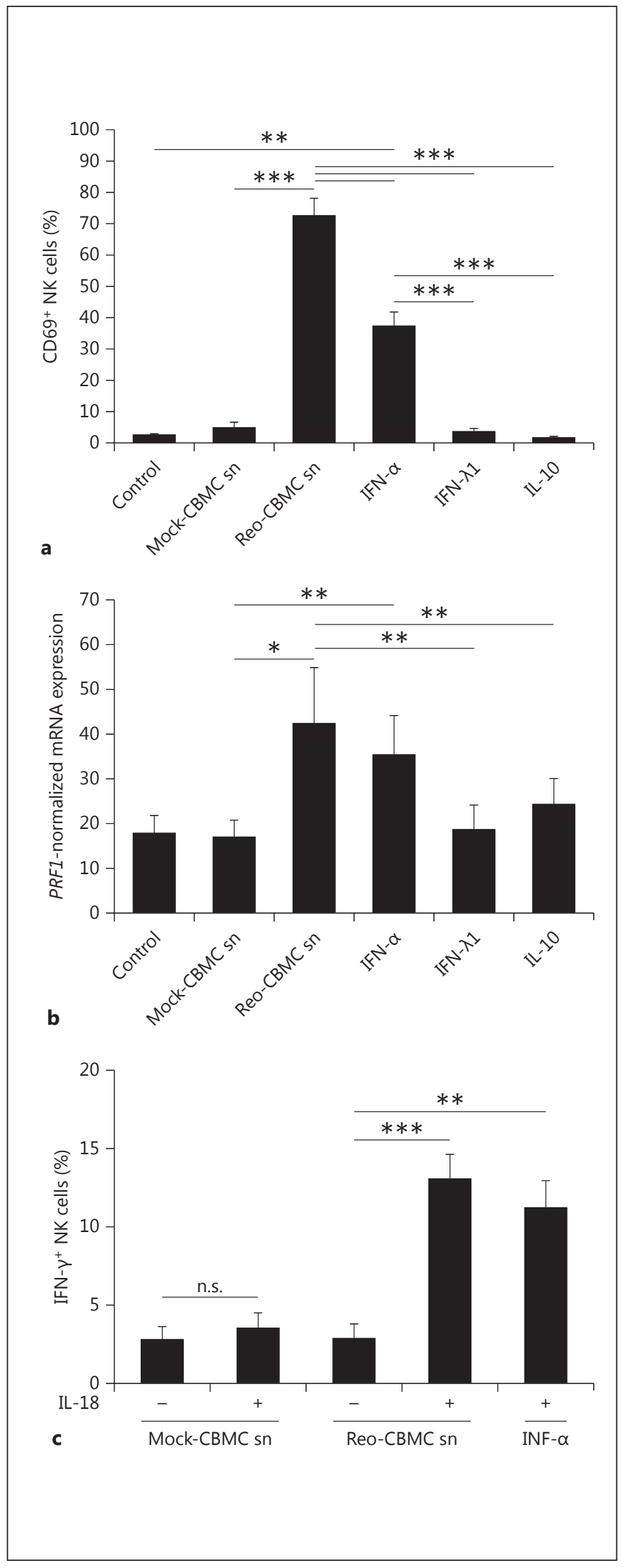

J Innate Immun 2017;9:94-108 DOI: $10.1159 / 000450576$ 

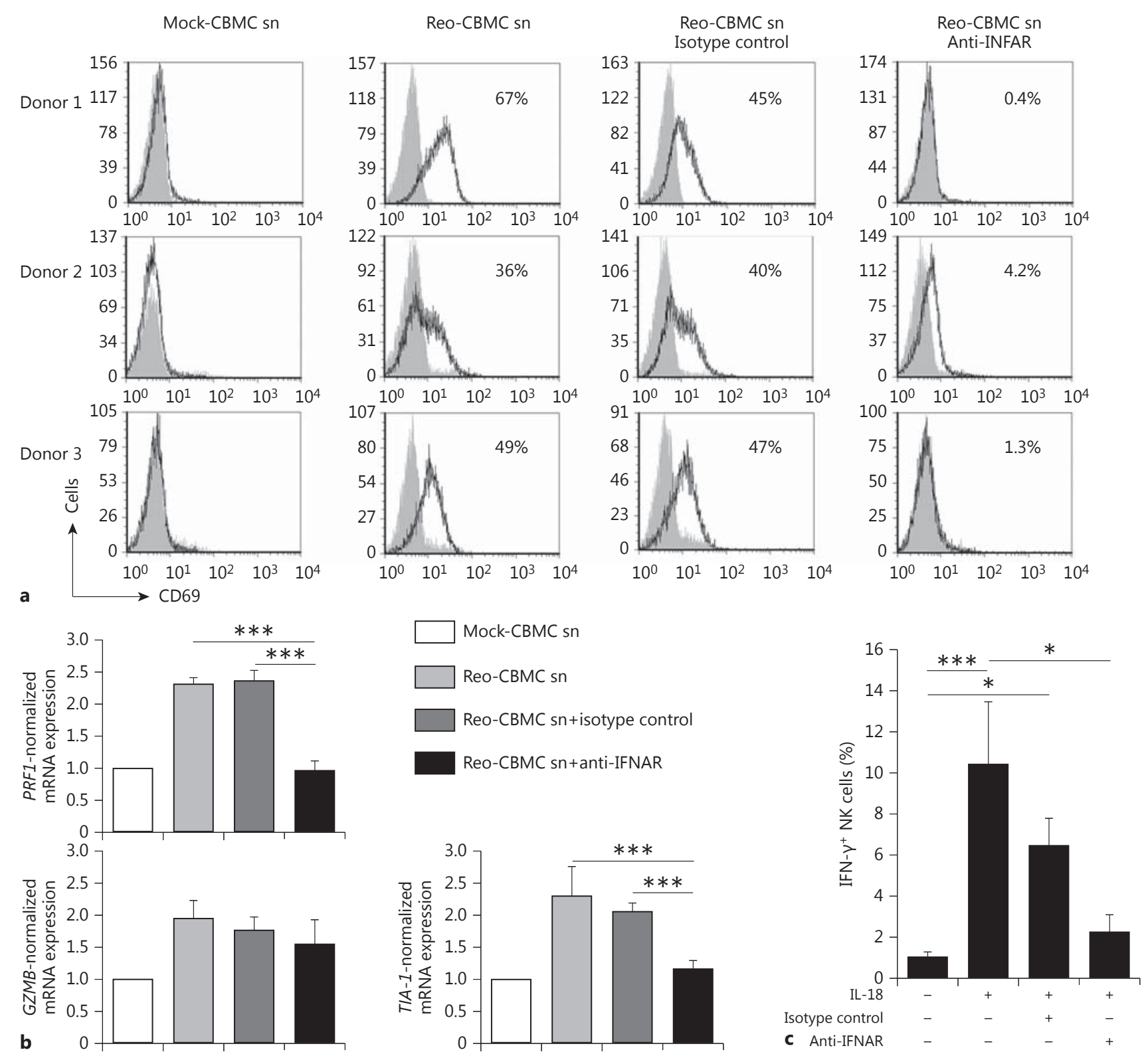

Fig. 5. Type I IFNs produced by reovirus-infected mast cells modulate NK cell activation. Purified NK cells were treated with $5 \mu \mathrm{g} /$ $\mathrm{ml}$ anti-IFNAR, $5 \mu \mathrm{g} / \mathrm{ml}$ mouse IgG2a (isotype control) or left untreated for $1.5 \mathrm{~h}$ in $10 \%$ RPMI, followed by stimulation with ReoCBMC sn for $24 \mathrm{~h}$. a The number of CD69 $9^{+}$NK cells (black line, empty histograms) and control staining (filled histograms) are shown. $\mathbf{b}$ The expression of the genes PRF1, GZMB and TIA-1 was normalized to GAPDH, which was carried out as the value of 2 to the power of the difference between the threshold cycles for the amplification of GAPDH and either PRF1, TIA-1 or GZMB, and then presented graphically relative to the mock-treated cells for each condition $(n=6)$. c IFN- $\gamma$ production in response to ReoCBMC sn plus IL-18 was analyzed by FACS $(n=8)$. Data were compared using repeated-measures ANOVA with the Dunn post hoc test. ${ }^{*} \mathrm{p}<0.05,{ }^{* * *} \mathrm{p}<0.001$. Results are presented as the mean \pm SEM from at least 3 independent experiments performed on at least 5 different NK cell donors. 
cells cultured with Reo-CBMC sn + IL-18 ( $>$ > 0.05; fig. 5c).

These results confirm that type I IFNs produced by virus-infected mast cells play a major role in modulating the activation of NK cells.

Mast Cells Are an Important Source of Antiviral IFNs

At mucosal surfaces, viruses infect both structural and immune sentinel cells. Most cells are capable of producing type I IFNs during viral infection, but the contribution of different cellular sources can vary. Therefore, the mast cell contribution to antiviral host responses through the production of type I IFNs was analyzed and compared with both NHLF and epithelial cells, such as Calu-3, which represent a good model of the proximal airway epithelium $[28,29]$.

Reovirus-infected mast cells demonstrated a substantially greater induction of the IFNA gene family and IFNB gene (fig. 6a) compared to Reo-NHLF at both 6 and $24 \mathrm{~h}$ (fig. 6b). In contrast, Reo-NHLF demonstrated substantial $I L-8(210.8 \pm 150.1$ normalized mRNA expression, $\mathrm{n}=4)$ and $I L-6$ (45.1 \pm 13.7 normalized mRNA expression, $\mathrm{n}=$ 3) gene expression compared to Mock-NHLF $(3.1 \pm 1.2$ and $6.7 \pm 0.5$, respectively), similarly to previous findings [30]. Reovirus-infected Calu-3 cells also demonstrated low type I IFN mRNA responses (fig. 6c) compared to Reo-CBMC but the levels of infection were similar $(>90 \%$ reovirus-positive cells; data not shown). Similar to NHLF and Calu-3, A549 (lung), Caco-2 (colonic) and Hela (cervical) epithelial cells showed a preferential induction of IFNB alone (fig. 6b, c; data not shown). In order to corroborate that the absent IFNA response by the epithelial cell lines was not due to an impaired IFN response, we included the analysis of NBEC in our study. Similarly, Reo-NBEC upregulated the IFNB gene expression at 6 and 24 h p.i., but the IFNA genes remained unaltered (fig. $6 \mathrm{~d}$ ). In addition, mast cell IFN responses were compared to those from MDDC, an important source of IFNs [31,32]. Our data show that Reo-CBMC upregulated IFNB and most IFNA genes at similar levels to Reo-MDDC at 6 and 24 h post-infection (p.i.). Only IFNA1 and IFNA14 genes were more highly upregulated by Reo-MDDC than by Reo-CBMC at 6 ( $\mathrm{n}=3$ and $\mathrm{n}=7$, respectively) and $24 \mathrm{~h}$ p.i. ( $\mathrm{n}=5$ and $\mathrm{n}=9$, respectively) (online suppl. table 1 ). In addition, the IFNA 8 gene was more highly expressed by Reo-MDDC at $6 \mathrm{~h}$ p.i. These results demonstrate that there are important differences in the quantity and profile of IFNs produced by virus-infected cells. Mast cells, being long-term, resident tissue cells, are particularly potent producers of a wide range of type I IFNs.

Virus-Infected Mast Cells Activate NK Cells

\section{Discussion}

Mast cells and NK cells play key roles in effective mucosal immunity. However, beyond the role of mast cells as a source of NK cell chemoattractants $[9,33]$, the functional interactions between these cells have not been well studied. We demonstrate that human mast cells express a range of potent cytokines, including IL-10, type I and type III IFNs and TNF in response to reovirus infection. We also showed, for the first time, that virus-infected human mast cells induce NK cell activation both in vivo and in vitro. In addition, enhanced NK cell cytotoxicity and IFN- $\gamma$ production were dependent on mast cell-derived type I IFNs, rather than on other mast cell products. Finally, mast cells, unlike epithelial cells and fibroblasts, upregulated the expression of all 12 IFN- $\alpha$ members, in addition to IFN- $\beta$. These IFN family members have been reported to have distinct immunomodulatory activities [34].

The ability of mast cell products to enhance the cytotoxic functions and promote IFN- $\gamma$ production of NK cells is of particular importance, given the strategic location of mast cells at mucosal surfaces. The chemotactic effect of mast cells on NK cells observed in our in vivo model (fig. 2a) could have been derived from the indirect effect of IFNs on chemokine production by murine cells or the direct effect of chemokines produced by ReoCBMC because chemokines derived from virus-infected mast cells have been demonstrated to selectively recruit NK cells $[9,33]$, which helps ensure that mast cells and NK cells are in close proximity at sites of infection.

Our data suggest that the capacity to recruit NK cells may be shared by virus-infected structural cells (fig. 2a). However, the data provided from our in vivo model confirm that human mast cells can also activate NK cells in vivo (fig. $2 \mathrm{~b}$ ). This is not a property shared by virus-infected fibroblasts, consistent with the finding of the greater diversity and strength of mast cell type I IFN responses.

The dramatic impact of IFNAR blockade on mast cell sn-induced NK cell effector functions (fig. 5) indicates that mast cell-derived type I IFNs, which are known to work across species barriers [21,22], were a principal regulator of NK responses in our experimental model. Although most cells produce type I IFNs in response to viruses, here, we show that the contribution of different cellular sources varies not only in quantity but also in quality. Fibroblasts and epithelial cells preferentially expressed IFN- $\beta$ upon viral infection as previously shown $[13,35,36]$. IFNB is an extremely potent antiviral agent in human respiratory epithelial cells [37] but is produced

J Innate Immun 2017;9:94-108

DOI: $10.1159 / 000450576$ 


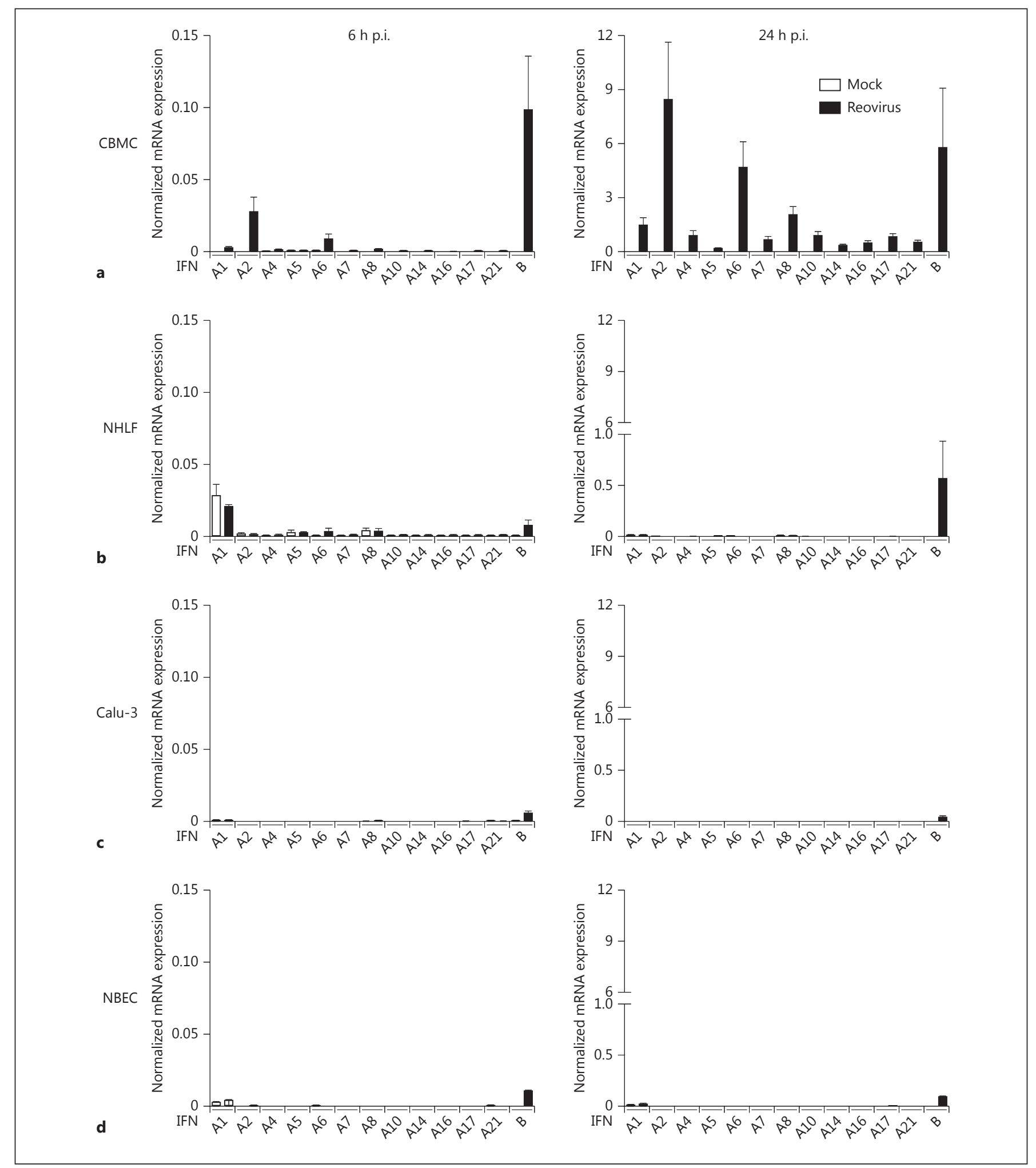

Fig. 6. Reovirus-infected human mast cells are an important source of type I IFNs. CBMC ( $\mathrm{n}=7$ and 9, a), NHLF ( $\mathrm{n}=4$ and 5, b), Calu-3 ( $\mathrm{n}=3$ and $4, \mathbf{c})$ and $\operatorname{NBEC}(\mathrm{n}=1$, d) were infected with reovirus or left uninfected (Mock) for 6 or $24 \mathrm{~h}$, respectively. Type
I IFN data are presented as normalized mRNA expression relative to HPRT. Data are shown as mean \pm SEM and are representative of at least 3 independent experiments. Where no bar is visible, no significant mRNA was detected. 
Fig. 7. Mast cells as sentinels in virus infections. Resident mature mast cells located close to blood vessels and epithelial barriers can recognize invading viruses and initiate innate immunity by recruitment and activation of NK cells through the production of CXCL8 and type I IFNs, respectively. Additional resident cells, such as fibroblasts, can also contribute to NK cell recruitment. At mucosal surfaces, the ability of mast cells, compared to structural cells, to express a wide range of IFNs- $\alpha(1-21)$ in addition to chemokines, may contribute to a more diverse cell infiltrate and more sustained IFN response, and therefore influence overall antiviral immunity. In addition to these mediators, mast cells can be considered as an important source of type III IFNs (IFN- $\lambda$ ), which have been reported to specifically protect epithelial surfaces more effectively than type I IFNs.

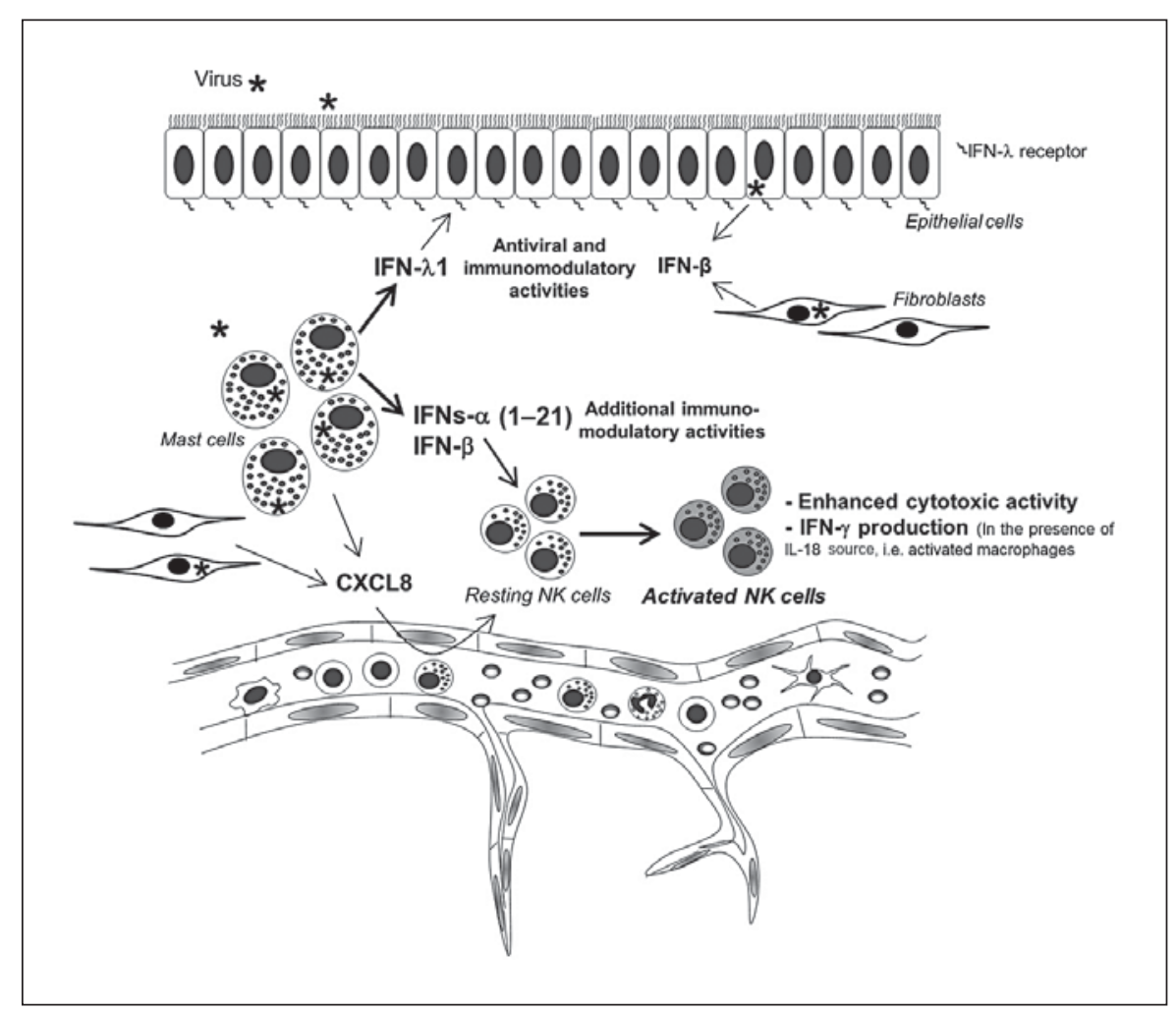

more transiently than IFN- $\alpha$. The classic pathway for type I IFN production relies on an initial production of IFN- $\beta$ by virus-infected cells (first wave), which triggers and enhances the production of IFN- $\alpha$ and IFN- $\beta$, respectively (second wave) [38]. Therefore, epithelial cell-derived IFN- $\beta$, produced in the early stage of viral infections, could be important for triggering IFN- $\alpha$ subtype production in resident cells such as mast cells.

Type III IFNs share biological activities with type I IFNs but these are mediated through the IFN- $\lambda$ receptor, composed of the IL-10 receptor $\beta$ and IL-28 receptor $\alpha$ subunits [27]. NK cells had minimal expression of the IL28 receptor a subunit, as analyzed by qPCR and FACS (data not shown). The target cells of type III IFNs have not been fully described. However, significant expression of IL-28 receptor a has been reported on epithelial cells of the respiratory, gastrointestinal and reproductive tracts [39], locations where mast cells are especially prominent. Murine models have demonstrated that intestinal epithelial cells respond strongly to IFN- $\lambda$ but only marginally to type I IFNs in vivo [40]. These results suggest a critical role for IFN- $\lambda$ in epithelial host defense and nonredundant functions to type I IFNs. Thus, at mucosal epithelial sites, mast cells would be well-placed to promote efficient, local, initial innate antiviral responses in epithelial cells through their type III IFN production (fig. 7).

IL-10 has previously been reported to be both produced and act upon mast cells [41], although not in the context of viral infection. The virus-induced mast cell production of IL-10 could potentially limit aspects of local inflammation. IL-10 has been reported to enhance the activation of NK cells $[18,25]$, but in our experiments, exogenous IL-10 stimulation of human NK cells did not upregulate CD69 protein (fig. 4a) nor did it induce the PRF1 and TIA-1 genes (fig. $4 \mathrm{~b}$ and data not shown, respectively) as reported by Mocellin et al. [18, $25]$; importantly, the levels of IL-10 produced by reovirus-infected mast cells were $90.8 \pm 18.5 \mathrm{pg} / \mathrm{ml} / \mathrm{million}$ cells, while the described concentration of exogenous IL-10 required to activate NK cells is much higher (5-30 $\mathrm{ng} / \mathrm{ml})$.

There are multiple sources of IFNs during human viral infections, but as resident, long-lived sentinel cells, mast cells are likely to be an important and sustained local source of type I IFNs below epithelial surfaces. For example, Respiratory syncytial virus (RSV) infection of airway epithelial cells was found to be only a relatively weak inducer of IFN- $\alpha$ [42], while RSV-infected mast cells 
showed a similar type I IFN production to Reo-CBMC (fig. 3), despite limited active RSV infection [43]. Plasmacytoid DC are a potentially more potent source of type I IFNs; they are not, however, generally observed in the steady state in normal skin and mucosal tissue [44] and may thus be of greater importance when virus infections become systemic [45]. In contrast, mature mast cells are numerous at most mucosal and skin sites $[5,46]$. Another important source of IFNs are classic DC [31,32], which reside as immature DC in peripheral tissues. Our data show that human mast cells upregulate type I IFN gene expression to levels similar to human MDDC in response to reovirus infection (online suppl. table 1). However, pathogen recognition by immature DC leads to their activation and migration to secondary lymph organs. Therefore, mature local mast cells can be considered as a continuous source of IFNs at sites of infection (fig. 6a; online suppl. table 1), contributing to the antiviral host response by actions on recruited NK cells and neighboring cells.

Antiviral responses, induced by distinct IFN- $\alpha$ members, show a great deal of similarity. However, important differences in IFN- $\alpha$ biological activities have been reported. For example, IFN- $\alpha 2$, but not IFN- $\alpha 8$, favored T cell recruitment [34]. The unusual profile of IFNs- $\alpha$ produced by mast cells, together with their unique chemokine profile in response to viral challenge, likely modifies the inflammatory cell infiltrate, thus influencing the developing immune response.

Asthmatic individuals have a dysfunctional response to viral infections, including rhinoviruses and RSV, commonly leading to asthma exacerbation [47]. Similarly, subjects with atopic dermatitis can develop recurrent and severe infection with HSV [48]. Some medications that are used to ameliorate allergy symptoms impact on mast cells by either reducing the cell numbers or by downregulating their function $[49,50]$. Epithelial cells from asthmatic patients have been shown to respond to exogenous IFN- $\beta[37,51]$ but their production of this cytokine in response to rhinovirus is poor [52]. It is not yet known if mast cells from disease sites in allergic patients have normal production of type I IFNs. Importantly, the efficient production of IFNs is not only associated with viral clearance, recent reports suggest an important role of type I IFNs in the regulation of Th2 responses [53, 54]. Kanazawa et al. [55] described that asthmatics undergoing IFN therapy for HCV infection had a reduction in asthma attacks. Poor production of type I IFNs could contribute to the development of Th2 responses. The role of mast cells in this context is unknown.
Overall, our data demonstrate that human mast cells are an important source of a range of type I and type III IFNs that contribute to antiviral host responses by inhibiting viral propagation and activating effector cells such as NK cells. NK cell cytotoxic function is enhanced by mast cell mediators produced in response to viral infection, and, in the context of IL-18, mast cell products also increase IFN- $\gamma$ production by NK cells. When considered together with the existing literature demonstrating mast cell-mediated NK cell chemotaxis, our findings suggest a novel mast cell-NK cell immune axis in the host defense against viral infection (fig. 7), which could be rapidly induced prior to the generation of acquired immunity. Such responses would be of particular importance for the early response to viral infection at mast cell-rich mucosal surfaces.

\section{Acknowledgements}

This work was supported by grants 147763 and 181205 from the Consejo Nacional de Ciencia y Tecnología (CONACYT), Mexico, and MOP-10966 from the Canadian Institutes of Health Research (CIHR). The authors thank Nong Xu, Yisong Wei and Cinera States for their excellent technical assistance and Dr. Elizabeth Cowley for providing Calu-3 cells and advice on epithelial cell culture.

\section{Disclosure Statement}

The authors declare no commercial or financial conflict of interest.

References

1 Bergelson JM: Virus interactions with mucosal surfaces: alternative receptors, alternative pathways. Curr Opin Microbiol 2003;6:386391

2 Lodoen MB, Lanier LL: Natural killer cells as an initial defense against pathogens. Curr Opin Immunol 2006;18:391-398.

3 Lanier LL: Up on the tightrope: natural killer cell activation and inhibition. Nat Immunol 2008;9:495-502.

4 Zwirner NW, Domaica CI: Cytokine regulation of natural killer cell effector functions. BioFactors (Oxford) 2010;36:274-288.

5 Abraham SN, St John AL: Mast cell-orchestrated immunity to pathogens. Nat Rev Immunol 2010;10:440-452.

6 Dawicki W, Jawdat DW, Xu N, Marshall JS: Mast cells, histamine, and IL-6 regulate the selective influx of dendritic cell subsets into an inflamed lymph node. J Immunol 2010; 184:2116-2123. 
7 Aoki R, Kawamura T, Goshima F, Ogawa Y, Nakae S, Nakao A, Moriishi K, Nishiyama Y, Shimada S: Mast cells play a key role in host defense against herpes simplex virus infection through TNF-alpha and IL-6 production. J Invest Dermatol 2013;133:2170-2179.

8 Graham AC, Hilmer KM, Zickovich JM, Obar JJ: Inflammatory response of mast cells during influenza A virus infection is mediated by active infection and RIG-I signaling. J Immunol (Baltimore, Md: 1950) 2013;190:46764684.

9 Burke SM, Issekutz TB, Mohan K, Lee PW, Shmulevitz M, Marshall JS: Human mast cell activation with virus-associated stimuli leads to the selective chemotaxis of natural killer cells by a CXCL8-dependent mechanism. Blood 2008;111:5467-5476.

10 Boehme KW, Lai CM, Dermody TS: Mechanisms of reovirus bloodstream dissemination. Adv Virus Res 2013;87:1-35.

11 Ambler L, Mackay M: Reovirus 1 and 3 bind and internalise at the apical surface of intestinal epithelial cells. Virology 1991;184:162169.

12 Errington F, Steele L, Prestwich R, Harrington KJ, Pandha HS, Vidal L, de Bono J, Selby P, Coffey M, Vile R, Melcher A: Reovirus activates human dendritic cells to promote innate antitumor immunity. J Immunol 2008; 180 : 6018-6026.

13 Stewart MJ, Smoak K, Blum MA, Sherry B: Basal and reovirus-induced beta interferon (IFN-beta) and IFN-beta-stimulated gene expression are cell type specific in the cardiac protective response. J Virol 2005;79:29792987.

14 Harrington KJ, Vile RG, Melcher A, Chester J, Pandha HS: Clinical trials with oncolytic reovirus: moving beyond phase I into combinations with standard therapeutics. Cytokine Growth Factor Rev 2010;21:91-98.

15 Enoksson M, Ejendal KF, McAlpine S, Nilsson G, Lunderius-Andersson C: Human cord blood-derived mast cells are activated by the Nod1 agonist M-triDAP to release pro-inflammatory cytokines and chemokines. J Innate Immun 2011;3:142-149.

16 Henney CS, Kuribayashi K, Kern DE, Gillis S: Interleukin-2 augments natural killer cell activity. Nature 1981;291:335-338.

17 Clausen J, Vergeiner B, Enk M, Petzer AL, Gastl G, Gunsilius E: Functional significance of the activation-associated receptors CD25 and CD69 on human NK-cells and NK-like T-cells. Immunobiology 2003;207:85-93.

18 Mocellin S, Panelli M, Wang E, Rossi CR, Pilati P, Nitti D, Lise M, Marincola FM: IL-10 stimulatory effects on human NK cells explored by gene profile analysis. Genes Immun 2004;5:621-630.

19 Pirhonen J, Sareneva T, Kurimoto M, Julkunen I, Matikainen S: Virus infection activates IL-1 beta and IL-18 production in human macrophages by a caspase-1-dependent pathway. J Immunol 1999;162:7322-7329.
20 Biron CA, Nguyen KB, Pien GC, Cousens LP, Salazar-Mather TP: Natural killer cells in antiviral defense: function and regulation by innate cytokines. Ann Rev Immunol 1999;17: 189-220.

21 Kubes M, Fuchsberger N, Kontsek P: Crossspecies antiviral and antiproliferative activity of human interferon-omega. J Interferon Res 1994;14:57-59.

22 Weber H, Valenzuela D, Lujber G, Gubler M, Weissmann C: Single amino acid changes that render human IFN-alpha 2 biologically active on mouse cells. EMBO J 1987;6:591-598.

23 Kataoka S, Satoh J, Fujiya H, Toyota T, Suzuki R, Itoh K, Kumagai K: Immunologic aspects of the nonobese diabetic (NOD) mouse. Abnormalities of cellular immunity. Diabetes 1983;32:247-253

24 Brouty-Boye D, Pottin-Clemenceau C, Doucet C, Jasmin C, Azzarone B: Chemokines and CD40 expression in human fibroblasts. Eur J Immunol 2000;30:914-919.

25 Mocellin S, Panelli MC, Wang E, Nagorsen D, Marincola FM: The dual role of IL-10. Trends Immunol 2003;24:36-43.

26 Liang S, Wei H, Sun R, Tian Z: IFNalpha regulates NK cell cytotoxicity through STAT1 pathway. Cytokine 2003;23:190-199.

27 Durbin RK, Kotenko SV, Durbin JE: Interferon induction and function at the mucosal surface. Immunol Rev 2013;255:25-39.

28 Harcourt JL, Caidi H, Anderson LJ, Haynes LM: Evaluation of the Calu-3 cell line as a model of in vitro respiratory syncytial virus infection. J Virol Methods 2011;174:144-149.

29 Hsu AC, Parsons K, Barr I, Lowther S, Middleton D, Hansbro PM, Wark PA: Critical role of constitutive type I interferon response in bronchial epithelial cell to influenza infection. PLoS One 2012;7:e32947.

30 Bedke N, Haitchi HM, Xatzipsalti M, Holgate ST, Davies DE: Contribution of bronchial fibroblasts to the antiviral response in asthma. J Immunol 2009;182:3660-3667.

31 Cella M, Salio M, Sakakibara Y, Langen H, Julkunen I, Lanzavecchia A: Maturation, activation, and protection of dendritic cells induced by double-stranded RNA. J Exp Med 1999; 189:821-829.

32 Montoya M, Schiavoni G, Mattei F, Gresser I, Belardelli F, Borrow P, Tough DF: Type I interferons produced by dendritic cells promote their phenotypic and functional activation. Blood 2002;99:3263-3271.

33 St John AL, Rathore AP, Yap H, Ng ML, Metcalfe DD, Vasudevan SG, Abraham SN: Immune surveillance by mast cells during dengue infection promotes natural killer (NK) and NKT-cell recruitment and viral clearance. Proc Natl Acad Sci USA 2011;108:91909195.

34 Foster GR, Masri SH, David R, Jones M, Datta A, Lombardi G, Runkell L, de Dios C, Sizing I, James MJ, Marelli-Berg FM: IFN-alpha subtypes differentially affect human $\mathrm{T}$ cell motility. J Immunol 2004;173:1663-1670.
35 Ohyama K, Sano T, Toyoda H: Predominant contribution of IFN-beta expression to apoptosis induction in human uterine cervical fibroblast cells by influenza-virus infection. Biol Pharm Bull 2004;27:1750-1757.

36 Tengroth L, Millrud CR, Kvarnhammar AM, Kumlien Georen S, Latif L, Cardell LO: Functional effects of Toll-like receptor (TLR)3, 7, 9, RIG-I and MDA-5 stimulation in nasal epithelial cells. PLoS One 2014;9:e98239.

37 Cakebread JA, Xu Y, Grainge C, Kehagia V, Howarth PH, Holgate ST, Davies DE: Exogenous IFN-beta has antiviral and anti-inflammatory properties in primary bronchial epithelial cells from asthmatic subjects exposed to rhinovirus. J Allergy Clin Immunol 2011; 127:1148-1154.e9.

38 Haller O, Kochs G, Weber F: The interferon response circuit: induction and suppression by pathogenic viruses. Virology 2006;344: 119-130.

39 Sommereyns C, Paul S, Staeheli P, Michiels T: IFN-lambda (IFN-lambda) is expressed in a tissue-dependent fashion and primarily acts on epithelial cells in vivo. PLoS Pathogens 2008;4:e1000017

40 Pott J, Mahlakõiv T, Mordstein M, Duerr CU, Michiels T, Stockinger S, Staeheli P, Hornef MW: IFN-lambda determines the intestinal epithelial antiviral host defense. Proc Natl Acad Sci USA 2011;108:7944-7949.

41 Marshall JS, Leal-Berumen I, Nielsen L, Glibetic M, Jordana M: Interleukin (IL)-10 inhibits long-term IL-6 production but not preformed mediator release from rat peritoneal mast cells. J Clin Invest 1996;97:1122-1128.

42 Schijf MA, Lukens MV, Kruijsen D, van Uden NO, Garssen J, Coenjaerts FE, Van't Land B, van Bleek GM: Respiratory syncytial virus induced type I IFN production by PDC is regulated by RSV-infected airway epithelial cells, RSV-exposed monocytes and virus specific antibodies. PLoS One 2013;8:e81695.

43 Al-Afif A, Alyazidi R, Oldford SA, Huang YY, King CA, Marr N, Haidl ID, Anderson R, Marshall JS: Respiratory syncytial virus infection of primary human mast cells induces the selective production of type I interferons, CXCL10, and CCL4. J Allergy Clin Immunol 2015;136:1346-1354.e1.

44 Gregorio J, Meller S, Conrad C, Di Nardo A, Homey B, Lauerma A, Arai N, Gallo RL, Digiovanni J, Gilliet M: Plasmacytoid dendritic cells sense skin injury and promote wound healing through type I interferons. J Exp Med 2010;207:2921-2930.

45 Kumagai Y, Takeuchi O, Kato H, Kumar H, Matsui K, Morii E, Aozasa K, Kawai T, Akira $S$ : Alveolar macrophages are the primary interferon-alpha producer in pulmonary infection with RNA viruses. Immunity 2007;27: 240-252.

46 Collington SJ, Williams TJ, Weller CL: Mechanisms underlying the localisation of mast cells in tissues. Trends Immunol 2011;32: 478-485. 
47 Jackson DJ, Johnston SL: The role of viruses in acute exacerbations of asthma. J Allergy Clin Immunol 2010;125:1178-1187; quiz 1188-1189.

48 Wollenberg A, Wetzel S, Burgdorf WH, Haas $\mathrm{J}$ : Viral infections in atopic dermatitis: pathogenic aspects and clinical management. J Allergy Clin Immunol 2003;112:667-674.

49 James A, Gyllfors P, Henriksson E, Dahlén SE, Adner M, Nilsson G, Dahlén B: Corticosteroid treatment selectively decreases mast cells in the smooth muscle and epithelium of asthmatic bronchi. Allergy 2012;67:958-961.
50 Peachell P: Targeting the mast cell in asthma. Curr Opin Pharmacol 2005;5:251-256.

51 Djukanovic R, Harrison T, Johnston SL, Gabbay F, Wark P, Thomson NC, Niven R, Singh D, Reddel HK, Davies DE, Marsden R, Boxall C, Dudley S, Plagnol V, Holgate ST, Monk P: The effect of inhaled IFN-beta on worsening of asthma symptoms caused by viral infections. A randomized trial. Am J Respir Crit Care Med 2014;190:145-154.

52 Wark PA, Johnston SL, Bucchieri F, Powell R, Puddicombe S, Laza-Stanca V, Holgate ST, Davies DE: Asthmatic bronchial epithelial cells have a deficient innate immune response to infection with rhinovirus. J Exp Med 2005; 201:937-947.
53 Huber JP, Ramos HJ, Gill MA, Farrar JD: Cutting edge: type I IFN reverses human Th2 commitment and stability by suppressing GATA3. J Immunol 2010;185:813-817.

54 Tilg H, Kaser A: Type I interferons and their therapeutic role in Th2-regulated inflammatory disorders. Exp Opin Biol Ther 2004;4: 469-481.

55 Kanazawa H, Mamoto T, Hirata K, Yoshikawa J: Interferon therapy induces the improvement of lung function by inhaled corticosteroid therapy in asthmatic patients with chronic hepatitis $\mathrm{C}$ virus infection: a preliminary study. Chest 2003;123:600-603.

\section{Erratum}

In the article by Merres et al., entitled 'Role of the cathelicidin-related antimicrobial peptide in inflammation and mortality in a mouse model of bacterial meningitis' [J Innate Immun 2014;6:205-218, DOI: 10.1159/000353645], the authors' contributions footnote should correctly read 'J.M. and J.H. contributed equally as first authors; S.C.T. and L.-O.B. contributed equally as senior authors'. 